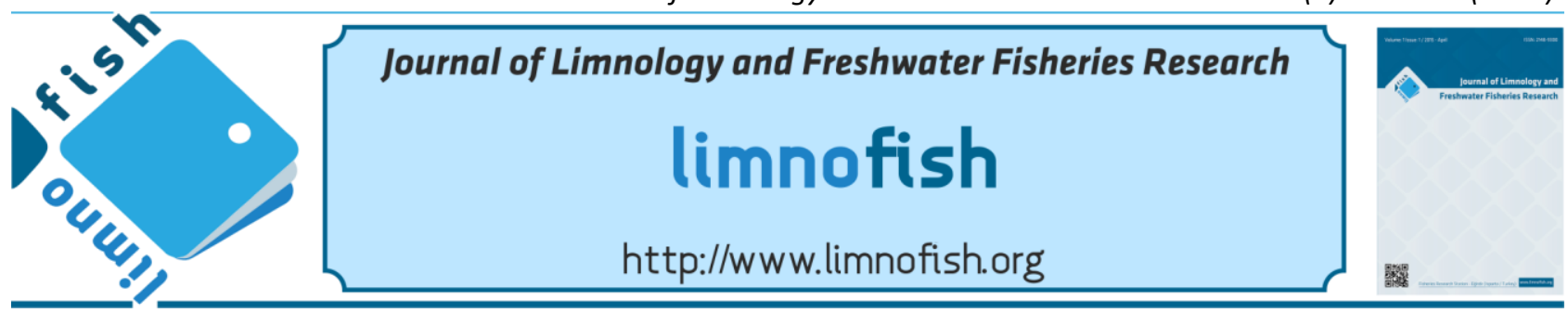

\title{
Management of Overfishing in the Inland Capture Fisheries in Nigeria
}

\author{
Olaniyi Alaba OLOPADE ${ }^{1 *(D)}$, Iyabo Olusola TAIWO ${ }^{2}{ }^{(D)}$, Henry Eyina DIENYE $^{1}$ (D) \\ ${ }^{1}$ Department of Fisheries, University of Port Harcourt, Rivers State, Nigeria. \\ ${ }^{2}$ Institute of Food Security, Environmental Resources \& Agricultural Research, Federal University of Agriculture Abeokuta, \\ Ogun State, Nigeria.
}

\section{A B STRACT}

Nigeria is endowed with extensive inland water bodies that are very rich in fish and shell fish many of which are of commercial importance. These diverse fish resources with immense potential plays contributing role to the food security and improving livelihoods of local fishers, but in recent years, there has been serious concern about the poor status of the inland capture fisheries. Overfishing has been recognized as a major threat to sustainability of the fisheries. Overfishing has brought about changes in species composition, decline yield and fish stocks are being threatened with depletion because of ineffectiveness and weak regulations. This paper elucidates and analyses the causes, signs and types of overfishing in the inland capture fisheries in Nigeria. It also highlights current management measures, reasons for management failure and some of the procedure that could be adapted for sustainable management of inland capture fisheries.

Keywords: Nigeria, inland, capture, fisheries, overfishing
ARTICLE INFO

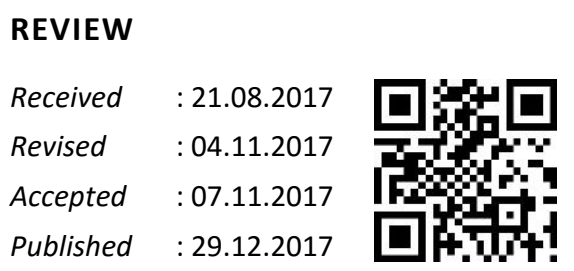

DOI: 10.17216/LimnoFish.335549

* CORRESPONDING AUTHOR

olaniyi.olopade@uniport.edu.ng

Phone: + 2348037154911

How to Cite

Olopade OA, Taiwo IO, Dienye HE. 2017. Management of Overfishing in the Inland Capture Fisheries in Nigeria. LimnoFish. 3(3):189-194. doi: 10.17216/LimnoFish.335549

\section{Introduction}

Nigeria has a wide variety inland waters which are rich in many and diverse finfish and shellfish. There are several significant riverine systems with about two thirds of the country lies in the watershed of the Niger River, and other major river systems include the Benue River, Cross River, Anambra River, Imo River, Kwa Iboe River, Ogun River and Oshun River (Olopade et al. 2017) and innumerable small rivers.

The most prominent amidst the networks in Nigeria is the Niger - Benue system, whereas Lake Chad and kanji are the most important with regards to fish production (Eyo and Ahmed 2005). These water bodies have been exploited by artisanal fishers operating in rivers, streams, estuaries, wetlands, brackish water, natural and man-made lakes for variety of benefits, including food security, livelihoods and employment.

In Nigeria, the inland capture fisheries is small scale and have been the most neglected by the government notwithstanding the major and the significant contribution of the sub-sector. The inland fisheries give about $82 \%$ of domestic fish production (FDF 1994). The catch of the inland capture fishery is dominated by Lates spp., Tilapia spp., Citharinus spp., Chrysichthys spp., Mormyrus spp. and Clarias spp. (Arawomo 2004).

For decades, the catches from the inland water bodies steadily increased with the many fish stocks are now classified as overfished due to continuous overfishing and use of obnoxious fishing methods such as the use of small mesh, unselective fishing gear, fish poisons and explosive. The overexploitation of the finite resources has led to a drastic reduction in inland rivers and lakes fish production from 213,996 metric tonnes in 1998 to 181,268 and 194,226 metric tonnes in 2000 and 2001 respectively (Eyo and Ahmed 2005).

The status of the inland capture fisheries in Nigeria is largely a result of a failure of the present process of fisheries governance which pose significant threats to the management of fisheries resources. The lack of effective governance can be attributed to outdated, weak and inappropriate regulations and incoherent policy. There is, however, 
a need to protect and sustainably manage inland capture fisheries in Nigeria that are essential to people. This paper examines causes, types and problems of overfishing in inland capture fisheries in Nigeria and subsequently recommending remedial actions.

\section{Inland fisheries resources and potentials in Nigeria}

Nigeria is watered from North to South and East to West by a network of rivers. Rivers Niger and Benue that form a big " $\mathrm{Y}$ " right across the middle of Nigeria originate from outside the country (Ajai 2012). The rivers of Nigeria may be divided into four main groups: 1) the Niger-Benue system, 2) the rivers west of the lower Niger, 3) the rivers east of the lower Niger and 4) those flowing into Lake Chad. All other rivers flow across the territory to empty into Lake Chad in the North-East corner or the Atlantic Ocean in the South.

The major rivers make up about 11.5 percent and lakes and reservoirs about 1 percent of the total area of Nigeria (Ajai 2012). The total water bodies, including deltas, estuaries, etc., make up about 15.9 percent of the total area of the country. The fresh water components are within extensive river systems, lakes, flood plains and reservoirs scattered over the entire land surface area of over 4,212,500 ha (Ita 1993). The brackish water sector consists of estuaries, beach ridges, intertidal mangrove swamps, intersecting rivers and winding saline creeks covering a total area of 1,751,509 ha (mostly unexploited). The estuarine resources alone are found in the extensive mangrove ecosystem estimated to cover an area of about 858,000 ha (Ita 1993) (Table 1).

Table 1: Area of inland water surface

\begin{tabular}{lr}
\hline Inland Water Resource & Area (ha) \\
\hline Freshwater Bodies (Basin \& Flood plains) & $3,221,500$ \\
Major Rivers & $10,812,400$ \\
Major Lakes \& Reservoirs & 853,600 \\
Deltas \& Estuaries & 858,000 \\
Minor Reservoirs & 98,900 \\
Miscellaneous wetlands & $4,108,100$ \\
Fish ponds & 5,500 \\
Total & $19,958,000$ \\
\hline
\end{tabular}

Freshwater has potential resources of $226,550 \mathrm{mt}$ for rivers/floodplains $160,000 \mathrm{mt}$ for Lake Chad, 38,000 mt for Kainji Lake and 2.5 million $\mathrm{mt}$ for aquaculture (FISON 2004). Ita (1993) emphasized that Nigerian inland water bodies are presently producing lower than $50 \%$ of their conjectured potential fisheries yields. The freshwater fish faunas of Nigeria have not been well document but recent information on species diversity in Nigerian freshwater reported 260 fish species. Given the diversity of freshwater fish assemblages, levels of fisheries productivity, cultural norms, density of human population and socioeconomic conditions, it is not surprising that there is immense variation in how, why and the extent to which freshwater fishes and other aquatic animals are exploited. The capture from inland waters are multi-species and multi-gear with a great majority of fishers traditionally operate at small-scale level to exploit the natural fisheries resources in whatever means available to them.

According to FAO (1997) the inland water resource has the following potentials:

(1) food fisheries based on wild stocks;

(2) enhancement of food fisheries in smaller water bodies and reservoirs;

(3) recreational fisheries, which are becoming more common in many areas of the world, and, where they develop, tend to supplant commercial food fisheries; and locally very intense exploitation of juvenile or small adults for stocking into other water bodies and/or aquaculture ponds, or for the ornamental fish trade (FAO 1997).

Based on above the inland capture fisheries in Nigeria is under exploited and less developed compared to other sectors such as oil, agriculture, industry and trade in Nigeria because fishing activities do not contribute significantly to the country's gross national product.

\section{Causes of overfishing}

The overfishing of Nigeria's inland capture fisheries began with introduction of synthetic fishing materials such as polyamide (nylon), polyester, polyethylene etc. Traditional materials for fishing have been replaced by modern ones which have increase fishing gears catchability and the most obvious effect is the depletion of some natural fish stocks. For example, the consequent of overfishing on a given species leads to immature populations with a fast turnover and high fecundity which result in a smaller and faster growing species as we are experiencing in most of inland waters in Nigeria. Kanji, Seisay and du Feu (1997) notice that a decline in mean sizes (mean length and weight) in fish species and changes in species composition due to other recruitment and ecosystem overfishing in Lake Kanji. Eyo (2004) reported a significant poaching of juvenile fishes on lake kanji by foreign fishermen who use gillnet and beach seine (Dala) less than 3 inches as specialized by the inland water decree. Therefore, there is the need for a new act which regulate the giving practice on Nigerian freshwater, which endured significant overfishing in current times (Eyo 2004). 
Obnoxious fishing practices: This may involve fishing with explosives and poisons that damage the ecosystem, killing most of the non-target species and compromising any possibility of sustaining yields in the future. Some toxic plant parts and their active ingredients in Nigerian inland waters are well described by Udolisa et al. (1994) and in Lake Kanji basin by Reed et al. (1967). The use of obnoxious fishing practices has been seen as a challenge in conserving the kanji and Jebba lakes (Nwabeze and Erie 2013).

Understanding of the nature small scale fishery is currently the most neglected component in the inland fisheries management. The fishers by nature are fiercely competitive and independent and do not easily respect fishing regulations. This can be traced to their poor socio economic status in the society. Persistent poverty among the fishers aggravate illegal practices, overfishing and habitat destruction in order to survive (Lacanilao 1998).

Other causes of overfishing include:

i) Difficulties in regulating fishing areas due to lack of resources and tracking activity,

ii) There are little to no rules regarding fishing practices,

iii) Lack of knowledge regarding fish populations.

iv) Unreported fishing, which is nearly impossible to track, partly because of the diffuse and small-scale nature of individual fisheries, the lack of easily definable landings, and because much of the catch goes directly to domestic consumption (Welcomme 1976)

\section{Types of overfishing}

Overfishing of stocks is not only an ecological problem but also economical problem. Based on these there are four recognised types of over fishing;

i) Growth overfishing: this occurs where the young fish (recruits) are harvested at an average size that is smaller than the size that would produce maximum yield per recruit,

ii) Recruitment overfishing: This occurs where the parent stock is so reduced that not enough young are produced by the fishery to maintain itself,

iii) Ecosystem overfishing: This occurs where species distribution is drastically changed, altering the efficiency of the system. In this situation, the niche inhabited by originally abundant species is not fully taken up by other species, changing the system's productivity,

iv) Economic overfishing: This occurs where the cost of fishing effort is greater than the revenue generated from the fishing. As fish stocks decline, the effort required to catch a given quantity of fish increases.

Research have shown that all these various forms of overfishing have being recorded in the inland water bodies in Nigeria.

\section{Signs of overfishing}

Basically the declines in the size of annual catch is important sign that the stock size is overfished and also, the quantity of sexually mature adult fish the spawners because they determine how many offspring are produced. According to Ita (1993) signs of overfishing are as follows:

i) General decline in catch per unit effort and observation that the increase in fishing effort does not result in a proportional increase in the catch.

ii) Reduction in genetic diversity, especially when the stock size is greatly reduced from natural level.

iii) Decline in catches in larger mesh net, results into high catch in small mesh net.

iv) Low productivity of the littoral zone.

v) High concentration of fishermen per unit length of shore land per surface area.

vi) Rise in the cost of catching a unit weight of fish associated with increase in effort without relative increase in catch.

vii) Mass migration of non-indigene fishermen to other places.

viii) Decrease in market landing as compared to previous year or season.

ix) Increase in the price of fish in an area which could be a sign of low harvest resulting from overfishing.

x) When so fewer age groups are represented in catches (Rosenberg and Restrepo 1995).

xi) Frequent damage or destroy of passive fishing gears as result of competition for a dwindling resource base. This in turn has contributed to social unrest and inability of fishing community to organise for social, economic or political purposes (Bailey 1987).

xii) The contribution of capture inland fish to food security has been largely ignored and priorities switched to other sectors. 


\section{Management of Inland Capture Fisheries in Nigeria}

As far as fisheries management is concerned in Nigeria, the system is divided into two namely, government and traditional institutions. Traditional management systems entail the regulation of fisheries activities and resources by traditional authorities or communities using common beliefs or norms, prescriptions, religious practices, behaviours, taboos, magic, languages and such systems are still operational in spite of the population growth, changes in legal systems, urbanization, commercialisation and technological change. In general, there are no customary restrictions to access water from large sources but customary law disapproves of the abuse of these rights. For examples fishing in rivers and streams is generally unrestricted but there may be a right to tribute by the local head fisherman or traditional leader, usually by strangers and in some cases tax is levied on fishing activities and freight traffic (Ramazzoti 2008), but if flood waters completely cover a person's land, the rights over the land belong to him (Ezeomah 1985).

Most traditional fishing methods and management patterns are still applicable at the present time. Property rights are the bases for traditional management systems (Hall 1999). These systems are usually well enforced, as they tend to be self-policed by fishermen. Traditional systems management focuses on resolving gear use or allocation problems. Access control is enforced by fishermen and by local moral and political authority. Supernatural sanctions are probably the most effective punishment for poachers. However, there are a number of obstacles that might face the encouragement to use them. Among these obstacles are the social change, poverty and educational levels of the fishers. And therefore, these resource users are losing control of traditional authority for management and less effective.

The management of water and fisheries resources in Nigeria is undertaken by all levels of government - federal, state and local governments which often lead to legislative overlaps and conflicts. The federal government is involved in fisheries management through the activities of the Federal Department of Fisheries. Federal involvement in inland fisheries management varies considerably with most inland waters in Nigeria are managed by the individual states within which the waters are located. When inland waters border more than one state, the states involved usually collaborate to determine how the water will be managed but each state normally has its own regulations. The inland fisheries decree was promulgated to harmonise the administration, management, protection and improvement of inland water fisheries through the use of decree. The roles of the decree included:

i. Provision for licensing and identification of fishing craft.

ii. Restriction on the use of certain fishing gear.

iii. Prohibition of obnoxious fishing methods.

iv. Prohibition of unauthorised export or import of live fish.

v. Protection of fish products from contamination and infection.

Although, some states in Nigeria have promulgated their fisheries edicts, some of which are yet to be effectively implemented (Ita 1993) and out of the 36 states, only 15 states have fisheries edicts, laws or regulations in place. However, where the framework is in place, the capacity to implement and enforce it is weak or nonexistent. Therefore the inland fisheries edicts is devoid of detailed regulations, outdated and not complemented by sufficient administrative structures, processes and institutions for its administration, largely due to lack of resources, weak database and weak law enforcement.

With the failure of centralized public sector control in fisheries management, collaborative management, or comanagement, has emerged as one of the most promising approaches to arrive at more sustainable forms of fisheries management. Cogovernance or Comanagement arrangements range from those that are largely consultative, to those in which the fishers design, implement, and enforce laws and regulations with advice from the government (Berkes 1994). In Nigeria, this type of management is commonly seen in communal water bodies. A typical example is being practised by the Argungu Emirate council of Kebbi state, where the use of gillnet and cast net are prohibited (Eyo and Ahmed 2005); this is to conserve the resource for the popular Argungu festival and in communal fish shelter popularly called acadja widely spread in most inland water bodies in Nigeria (Olopade et al. 2008).

\section{Reasons for management failure of} overfishing in inland fisheries in Nigeria

For many years, authorities have been attempting to control fishing with a variety regulating instrument in order to conserve the stocks. However, many of these measures fail because of the following:

1. To date, regulating overfishing have been very difficult. Enforcement tend to be weak because fisheries department in Nigeria is understaffed and underfunded.

2. "Tragedy of the common" (Hardin 1968); in Nigeria, most inland capture fisheries are generally considered as common property 
and some are entirely open-access to the effect that no one feels ownership or responsibilities for damage and in addition to short sightedness and greed of the fishers.

3. Failure to incorporate both scientific uncertainty and measurement error in stock assessments (Hilborn and Peterman 1995).

4. Lack of political will to implement scientific regulations and other recommendation measures.

5. Lack of know regarding fish populations.

6. The low level of organisation of small-scale fishers in most fishing settlements or villages has hindered their participation in fisheries governance

7. Lastly, most inland water bodies and landing sites are largely in remote areas making them inaccessible for proper management.

\section{Discussion}

Control of fishing effort is a basic tool of fisheries management. Although both the government and tradition institutions and lately comanagement are involved in the management of inland capture fisheries in Nigeria. The governments retain rights over resources, or lease or cede them to local communities. In order to reduce or totally eradicate the challenges being faced in the management of overfishing in inland capture fisheries and ensure sustainability and increase in fish production. The following is recommended:

1. Education is considered as a key component in the effective management systems of all successful fisheries. Fishers must be educated to use prescribed mesh sized net, so that under sized fishes would not be killed.

2. Existing illegal and indiscriminate fishing practice must be strictly checked by imposing stringent laws and penalties.

3. Government should allocate more policy attention and resources to develop inland capture fisheries in Nigeria.

4. Small scale fisheries development requires special support from government. An integrated approach through, and with the participation of, fishing communities is often the best way of channelling technical, financial and other form of assistance.

5. Restocking and stock enhancement programs should be introducing in most inland water by releasing reared juveniles into open waters has proven to be very effective for some species.

\section{References}

Ajai O. 2012. Law, Water and Sustainable Development: Framework of Nigerian Law. Law, Environment and Development Journal 8(1):89-115.

Arawomo GAO 2004. Self-sufficiency in fish production in Nigeria. Obafemi Awolowo University Inaugural Lecture Series No 165; Ile Ife, Nigeria

Bailey C. 1987. Social consequences of excess fishing effort. In: Proceedings, Symposium on the Exploitation and Management of Marine Fishery Resources in Southeast Asia. RAPA Report: 1978/10:30-1064.

Berkes F. 1994. "Co-management: Bridging the Two Solitudes. Northern Perspectives 22 (2-3):18-20.

Eyo AA. 2004. Provost alerts federal government over foreign fisherman in Lake Kanji. Guardian Newspaper. 21(9):451 pp. 50

Eyo AA, Ahmed YB. 2005. Management of inland capture fisheries and challenges to fish production in Nigeria. Paper presented at: $19^{\text {th }}$ Annual Conference of Fisheries Society of Nigeria (FISON); Ilorin, Nigeria.

Ezeomah C. 1985. Land tenure constraints associated with some recent experiments to bring formal education to nomadic fulani in Nigeria; [cited 2107 Aug 15] Available from http://www.odi.org.uk/pdn/papers

FAO 1997. Fisheries management. FAO technical guideline for responsible fisheries no 4. Rome: FAO. Report No.:4-82

Federal Department of Fisheries (FDF) 1994. Federal Statistics of Nigeria, published by Federal Department of Fisheries Nigeria. Second Edition, 20p

FISON 2004. Fisheries Society of Nigeria 25 years of Evolution and Metamorphous 1976-2001 Lagos: FISON Publication 110 pp.

Hall SJ. 1999. The effects of fishing on marine ecosystems and communities. Oxford:Blackwell Science $403 \mathrm{p}$.

Hardin G. 1968. "The tragedy of the commons". Science 162(12):43-48.

Hilborn RM, Peterman RM. 1995. The development of scientific advice with incomplete information in the context of the precautionary approach. In: FAO (1995) Precautionary approaches to fisheries.Part2: Scientific paper. FAO Fisheries Technical Paper No.: 350/2

Ita EO. 1993. Inland fisheries resource of Nigeria. Rome, FAO: CIFA Occasional Paper No.:20-120.

Lacanilao F. 1998. State of Philippine coastal fisheries. SEAFDEC Asian Aquaculture 20(6):14-17

Nwabeze GO, Erie AP. 2013. Artisanal fishers, 'use of sustainable fisheries management practice in Jebba Lake basin, Nigeria. Journal of Agric Extension, 17 (1): 123-134.

Olopade OA, Taiwo IO, Ajibade D, Aluko FA. 2008. Community participation in fishery management: A case study of acadja in Badagry Creeks, Ogun State, Nigeria. Journal of_Agriculture and Social Research 8(1):28-33. doi: 10.4314 /jasr.v8i1.2882 
Olopade OA, Sinclair NG, Dienye H. 2017. Fish catch composition of selected small scale fishing gears used in the Bonny River, Rivers State, Nigeria. Journal of Fisheries 5(1): 455-460. doi:10.17017/jfish.v5i1.2017.173

Ramazzoti M. 2008. 'Customary water rights and contemporary legislation: Mapping out the interface', FAO Legal Paper Online No. 76; [cited 2017 Aug] Available from www.fao.org/legal/prs-ol/lpo76.pdf

Reed W, Burchad, Hopson AJ, Jannes J, Yaro I. 1967. Fish and fisheries of northern Nigeria. Northern Nigeria: Ministry of Agriculture $226 \mathrm{p}$.

Rosenberg AA, Restrepo VR. 1995. Uncertainty and risk evaluation in stock assessment advice for U.S. marine fisheries. Can J Fish Aquat Sci. 51 (12): 2715-2720 doi: 10.1139/f94-271

Seisay MDB, du Feu TA. 1997. The effect of long term exploitation, by gill net fishery on the multi-species fish stocks in Kanji Lake. Nigeria: Nigerian-Germany Kainji Lake Fisheries Promotion Project Technical Report. Series No.: 1158.

Udolisa REK, Solar BB, in Lebo P, Ambrose EE. 1994. A Catalogue of small scale fishing gear in Nigeria. RAFR Publication Report No.: 014/F1/94/02- 142.

Welcomme RL. 1976. Fisheries ecology of floodplains rivers. London: Longman 3176 p. 